Ahmedin Lekpek

Državni univerzitet

u Novom Pazaru

alekpek@np.ac.rs

Prevod

obezbedio

autor
ISLAMSKE BANKE VS INVESTICIONI

FONDOVI: STATUS ULAGAČA U TEORIJI I PRAKSI

\title{
Rezime
}

Sa teoretskog aspekta, između islamskih banaka i konvencionalnih investicionih fondova postoje izvesne sličnosti, naročito po pitanju načina prikupljanja finansijskih sredstava. U radu se navedena sličnost testira i sa aspekta prakse. Poseban fokus je stavljen na prednosti i nedostatke statusa ulagača navedenih finansijskih institucija. Cilj rada je da kroz poređenje islamskih banaka sa opštepoznatim konvencionalnim finansijskim institucijama, poput investicionih fondova, čitaocima približi koncept islamskog bankarstva, koji je još uvek domaćoj javnosti nedovoljno poznat ili čak potpuno nepoznat. U radu dominira komparativna metoda, putem koje se upoređuju statusi ulagača islamske banke i investicionih fondova. Značaj zaključaka rada se ogleda u tome što se čitaocima daje kvalitetna osnova da islamske banke, čiji se dolazak u Srbiju može očekivati u dogledno vreme, mogu sagledati objektivno, uzimajući u obzir prevashodno ekonomske principe, koristi i probleme saradnje sa islamskim bankama.

Ključne reči: islam, bankarstvo, akcionari, deponenti, agencijski problem

JEL: G21, G23 


\section{ISLAMIC BANKS VS. INVESTMENT FUNDS: INVESTORS' STATUS IN THEORY AND PRACTICE}

Ahmedin Lekpek

State University of Novi Pazar alekpek@np.ac.rs

Translation provided by the author

\section{Summary}

From a theoretical point of view, there are certain similarities between Islamic banks and conventional mutual funds, particularly in terms of the fundraising methods. In the paper, we tested that similarity from the practical aspect. A special emphasis is on the advantages and disadvantages of the previously mentioned financial institutions investors' status. The aim of this study is to compare Islamic banks with generally known conventional financial institutions, such as mutual funds, and, in that way, enable the readers a better understanding of the Islamic banking concept, which is still relatively or completely unknown to the domestic public. The research is based on the comparative method by which we compared the investor's status in Islamic banks and their status in mutual funds. The significance of this paper's conclusions is reflected in the fact that readers are given a good basis to regard Islamic banks, whose arrival in Serbia can be expected in the foreseeable future, objectively, taking into consideration primarily the economic principles, benefits and problems of cooperation with Islamic banks.

Keywords: Islam, banking, shareholders, depositors, agency problem

JEL: G21, G23 


\section{Uvod}

"Investicioni fond je vrsta investicione kompanije koja prikuplja novac od mnogih investitora i ulaže ga u akcije, obveznice, instrumente tržišta novca i ostale hartije od vrednosti, ili čak u gotov novac" (U.S. Securities and Exchange Commission). Prve investicione fondove stvorili su holandski trgovci krajem 18. veka, ali su ove finansijske institucije puni zamah u razvoju doživele tek sa pojavom na tržištima Velike Britanije i Sjedinjenih Američkih Država, u drugoj polovini i krajem 19. veka (Rouwenhorst, 2004). Tokom poslednjih sto godina postojanja, investicioni fondovi su prolazili kroz periode uspona (nakon Drugog svetskog rata i tokom 90-tih godina) i padova (period Velike depresije i aktuelna finansijska kriza), ali su pokazali vitalnost, stabilnost i sposobnost brzog oporavka od teških izazova. O tome svedoče podaci da je ukupna vrednost neto aktive na globalnom nivou, nakon drastičnog pada tokom 2008. godine, već 2012. godine dostigla pretkrizni nivo (nivo iz 2007. godine), a u 2013. i 2014. čak ga i nadmašila (2007 - \$26.130.201 miliona, 2013 - \$30,047,406 miliona, 2014 - \$31,381,425 miliona) (Investment Company Institute, 2015). Postoji više podela investicionih fondova, od kojih se najčešće navodi sledeća (Investment Company Act, 1940; Erić, 2003): 1. otvoreni investicioni fondovi (open-end funds), 2. zatvoreni investicioni fondovi (closed-end funds) i 3. investicioni trastovi sa udelima (unit investment trusts). Investicioni fondovi emituju investicione jedinice kao "specifične sertifikate o vlasničkom ulaganju u fond, koji ulagaču daju pravo na pro rata neto imovinu fonda i prinose koje fond ostvaruje investicionom delatnošću“ (Marinković, 2008, str. 172). Otvoreni investicioni fondovi pružaju sigurnost investitorima jer im daju mogućnost da u svakom momentu prodaju svoje investicione jedinice fondu, što investicione jedinice ovih fondova čini veoma likvidnim. Iz tog razloga, otvoreni investicioni fondovi su najzastupljeniji na tržištu, što se može videti iz podatka da je $87 \%$ vrednosti neto aktive svih fondova u SAD u njihovom posedu (Investment Company Institute, 2015).

Ulaganje $\mathrm{u}$ investicione fondove ima izvesne prednosti, ali i nedostatke (Pozen and Hamacher, 2011, str. 5-9). Investicioni fondovi daju mogućnost "malim" investitorima da steknu udeo u vlasništvu nad diversifikovanim i stručno vođenim portfeljom, što im pruža sigurnost i šansu ostvarenja znatno većeg prinosa nego pri individualnom investiranju. Istovremeno ulagači $u$ fond gube mogućnost da aktivnije utiču na kreiranje portfelja, opterećeni su raznim vrstama troškova (Marinković, 2008, str. 182-184) i njihov je interes često podređen interesu menadžera fonda, koji znaju da zloupotrebe svoju poziciju i da deluju na štetu samih ulagača (Mahoney, 2004).

Islamsko bankarstvo je model finansijskog posredovanja zasnovan na šerijatskim principima (Rahman, 2005). Ovaj model podrazumeva: zabranu upotrebe kamate u poslovanju (Chapra, 2000; Siddiqi, 2004; Chapra, 2006; Iqbal and Mirakhor, 2009), potpunu informisanost svih ugovornih strana o ključnim elementima dogovorenog posla (zabrana garara) (Al-Dhareer, 1997), izbegavanje šerijatski zabranjenih (haram) poslova (Ayub, 2007), stremljenje socijalno odgovornom poslovanju (Farook, 2007; Dusuki and Dar, 2007; Yusuf and Bahari, 2011) i ostvarivanju socio-ekonomske pravde, kao ključnog cilja šerijatski uređenog društva (Khan and Bhatti, 2008). Polazeći od navedenih principa, islamski verski i ekonomski stručnjaci su vremenom razvili niz šerijatski usklađenih poslovnih ugovora, na kojima se zasniva islamsko bankarsko poslovanje (Usmani, 2003; Hadžić, 2005; Ayub, 2007; Iqbal and Mirakhor, 2009; Lekpek, 2013): ugovori o partnerskom ulaganju (mušareka/musharakah i mudareba/ mudarabah), ugovori o kupoprodaji (murabeha/ murabahah, selem/bay' al-salam i istisna'/bay' alistisna'), ugovor o zakupu (idžara/ijarah), ugovor o beskamatnom kreditu (kard hasan/qard hassan) i drugi ugovori, zasnovani na pružanju usluga posredovanja, savetovanja i davanja garancije. Ovi poslovi se najčešće realizuju u vidu plasmana islamske banke, dok u izvorima dominiraju depoziti. U islamskom bankarstvu postoje dve vrste depozita (Van Greuning and Iqbal, 2008, str. 193-196): transakcioni, koji se mogu povući u svakom trenutku i na koje banka ne plaća naknadu deponentu, i investicioni, kod kojih banke imaju partnerski odnos sa deponentom, odnosno sa njim dele dobitak i gubitak shodno unapred dogovorenom ključu 


\section{Introduction}

"Investment fund is a type of investment company that pools money from many investors and invests the money in stocks, bonds, money-market instruments, other securities, or even cash" (U.S. Securities and Exchange Commission). The first investment funds were created by traders from the Netherlands towards the end of the 18th century, but these financial institutions started to be fully developed only after their emergence on the market of Great Britain and the United States of America, in the second half and towards the end of the 19th century (Rouwenhorst, 2004). During the last 100 years of their existence, investment funds went through periods of ups (after the Second World War and in the 1990s) and downs (Great Depression and the current financial crisis), but they showed vitality, stability and ability for fast recovery and overcoming of difficult challenges. The supporting evidence behind this is the data showing the total net asset value at the global level which, after a drastic fall during the 2008 crisis, reached its pre-crisis levels in 2012 (same level it had in 2007), and in 2013 and 2014, it even surpassed the levels from 2007 (2007 - \$26,130,201 million, 2013 $\$ 30,047,406$ million, 2014 - \$31,381,425 million) (Investment Company Institute, 2015). There are several divisions of investment funds, the following being the most commonly referred to (Investment Company Act, 1940; Erić, 2003): 1. open-end funds, 2. closed-end funds and 3. unit investment funds. Investment funds issue investment units as "specific certificates of equity investment into fund, which give the investor right for pro rata share of the fund's net asset and profit which fund achieves through investment activities" (Marinković, 2008, p. 172). Open-end funds provide security to the investors because they give them the possibility to sell back, in any given moment, their investment units to the fund, which makes these investment units very liquid. Therefore, open-end funds are most common on the market, which can be seen from the data showing that $87 \%$ of total US investment funds' net asset is owned by them (Investment Company Institute, 2015).

Investing in investment funds has both advantages and disadvantages (Pozen and Hamacher, 2011, p. 5-9). Investment funds give possibility to "small" investors to gain part ownership over diversified and professionally managed portfolio, which gives them security and opportunity to achieve significantly higher yields than with individual investments. At the same time, the fund's investors lose their ability to actively influence the creation of a portfolio and they are burdened with various types of costs (Marinković, 2008, p. 182-184). Moreover, their interest is often subordinate to the interest of the fund managers, who have a tendency to abuse their position and act to the detriment of investors (Mahoney, 2004).

Islamic banking is a model of financial intermediation which is based on Sharia principles (Rahman, 2005). This model includes: prohibition of using interest (Chapra, 2000; Siddiqi, 2004; Chapra, 2006; Iqbal and Mirakhor, 2009), ensuring that all signatories are completely informed about the key elements related to the conducted business (prohibition of garar) (Al-Dhareer, 1997), avoidance of business prohibited by Sharia law (haram) (Ayub, 2007) and aiming to accomplish socially responsible business (Farook, 2007; Dusuki and Dar, 2007; Yusuf and Bahari, 2011) and accomplishing socio-economic justice, as the main aim of Sharia ordered society (Khan and Bhatti, 2008). Starting from the mentioned principles, Islamic religious and economic experts have over time developed a range of Sharia compliant commercial contracts, on which Islamic banking is based (Usmani, 2003; Hadžić, 2005; Ayub, 2007; Iqbal and Mirakhor, 2009; Lekpek, 2013): partnership investment contracts (musharakah and mudarabah), trade contracts (murabahah, bay' al-salam and bay' al-istisna'), lease contracts (ijarah), interestfree credit contracts (qard hassan) and other contracts, based on providing intermediation services, counseling and guarantees. These operations are often realized in the form of placements by Islamic banks, with deposits being dominant sources. In Islamic banking, there are two types of deposits (Van Greuning and Iqbal, 2008, p. 193-196): transaction (current) deposits, which can be withdrawn at any time and on which the bank does not pay compensation to the depositor, and investment 
podele i koji mogu da budu opšti, gde deponenti nemaju pravo odabira projekta u koji će novac biti uložen, i posebni (ograničeni) - gde deponenti postaju partneri banke u konkretnom projektu. Pored depozita, islamske banke se finansiraju i emisijom i prodajom običnih akcija, kao i zaduživanjem na beskamatnoj osnovi.

$\mathrm{Na}$ osnovu navedenih karakteristika investicionih fondova i islamskih banaka, sagledaćemo sličnosti i razlike koje među njima postoje, posebno se fokusirajući na status ulagača. Pritom, ne treba smetnuti s uma da na islamskom finansijskom tržištu posluju i šerijatski usklađeni investicioni fondovi. Oni su veoma slični konvencionalnim investicionim fondovima jer na isti način prikupljaju sredstva, ali se razlikuju po načinu plasmana prikupljenog novca (Elfakhani, Sidani and Fahel, 2004). Islamski investicioni fondovi uglavnom posluju po sistemu mudarebe, gde je menadžer fonda mudarib (upravlja imovinom fonda), dok ulagači u fond imaju ulogu rab ul-mala (investitora bez prava na upravljanje fondom). Ovi fondovi mogu biti mešoviti ili specijalizovani za vlasnička ulaganja, ulaganja u robu ili idžara (lizing) ulaganja, s tim što, kao i islamske banke, ne mogu investirati u kamatonosne instrumente i akcije preduzeća koja se bave šerijatski nedozvoljenim poslovima. Ipak, zbog lako uočljivih sličnosti i razlika između islamskih i konvencionalnih investicionih fondova, kao i zbog činjenice da je tržišni značaj islamskih investicionih fondova zanemarljiv, u ovom radu smo pažnju posvetili isključivo poređenju islamskih banaka i konvencionalnih investicionih fondova.

\section{Analiza statusa ulagača}

Islamske banke imaju izvesne sličnosti sa konvencionalnim investicionim fondovima, koje se ogledaju prevashodno $u$ načinu prikupljanja sredstava. Investicioni fondovi sredstva prikupljaju emisijom i prodajom investicionih jedinica, dok u islamskim bankama najveći deo izvora čine investicioni depoziti na bazi mudarebe, čiji vlasnici imaju prava i obaveze slične pravima i obavezama vlasnika investicionih jedinica. Međutim, islamske banke imaju i dodatne izvore finansiranja $u$ vidu transakcionih depozita čije su glavnice garantovane njihovim vlasnicima. Ovi depoziti se mogu povući u svakom trenutku, ali ne nose prinos svojim vlasnicima. Takođe, islamske banke se finansiraju emitovanjem običnih akcija, čiji vlasnici imaju veća prava nego vlasnici deonica investicionih fondova. Stoga se može zaključiti da islamske banke imaju znatno heterogeniju pasivu u odnosu na konvencionalne investicione fondove. Implikacije razlike $\mathrm{u}$ homogenosti pasiva islamskih banaka i investicionih fondova na najbolji način mogu se sagledati putem komparacije položaja vlasnika investicionih depozita islamskih banaka i vlasnika investicionih jedinica otvorenih investicionih fondova, koji imaju sledeća prava: pravo na udeo u dobiti, pravo na informisanost o poslovnim aktivnostima i pravo na povlačenje uloga. Komparacija statusa ova dva tipa ulagača se može vršiti s teoretskog i praktičnog aspekta.

Kod investicionih fondova praksa ne odstupa od teorije i tu se u ulozi ulagača uglavnom javljaju samo vlasnici investicionih jedinica. Sa druge strane, kod islamskih banaka postoje dve kategorije ulagača koji ostvaruju pravo na udeo $u$ dobiti: akcionari i vlasnici investicionih depozita. Njihovi statusi nisu jednaki jer akcionari imaju pravo na upravljanje bankom, kojim deponenti ne raspolažu. Samim tim, informacije su im dostupnije, što dovodi do pojave asimetrične informisanosti i stvara prostor za pojavu moralnog hazarda, odnosno zloupotrebu od strane akcionara na štetu deponenata (poput prikrivanja informacija o rizičnosti plasmana ili ostvarenom profitu). Polazeći od navedenog, možemo zaključiti da je, teoretski gledano, položaj vlasnika investicionih jedinica povoljniji u odnosu na položaj vlasnika investicionih depozita jer su prava svih ulagača kod investicionih fondova identična. Istina, $\mathrm{s}$ problemom neadekvatne informisanosti mogu se susresti i vlasnici investicionih jedinica, ali je njihov položaj sigurniji usled mogućnosti da u svakom trenutku povuku svoj ulog. Da bi ispunili obavezu isplate uloga u svakom trenutku, investicioni fondovi ulažu $\mathrm{u}$ visokolikvidne finansijske instrumente koji su lako utrživi, tako da u kratkom roku mogu obezbediti sredstva za isplatu odlazećim ulagačima. Povlačenje uloga je znatno komplikovanije u slučaju investicionih 
deposits, in which the bank has a partner relationship with the depositor, i.e. shares the profit and loss with the depositor according to the pre-signed agreement on sharing. These can be general (unrestricted), when depositors do not have the right to choose the project in which the money will be invested, and special (restricted) - where depositors become partners of the bank in respect of concrete projects. In addition to deposits, Islamic banks are financed by issuing and selling ordinary shares, as well by borrowing on the non-interest basis.

Based on the above mentioned characteristics of investment funds and Islamic banks, this paper will focus on analyzing the similarities and differences between them, especially focusing on the status of the investors. Moreover, it is important to remember that in the Islamic financial market, the investment funds operating in accordance to the Sharia law are also present. They are very similar to conventional investment funds because they collect money in the same ways but they differ in terms of the ways of investing the collected money (Elfakhani, Sidani and Fahel, 2004). Islamic investment funds generally operate by utilizing mudarabah system, where the fund manager is mudarib (who manages the assets of the fund), while investors in the fund have a role of rab ul-mal (investors without the right to manage the fund). These funds may be mixed or specialized for equity investment, investment in goods or Ijarah (leasing) investment, but, like Islamic banks, they cannot invest in interestbearing instruments and shares of companies that perform operations forbidden by the Sharia law. However, due to the easily observable similarities and differences between Islamic and conventional investment funds, as well as the fact that the market importance of Islamic investment funds is negligible, in this study, we are focused on comparison between Islamic banks and conventional investment funds.

\section{Analysis of investors' status}

Islamic banks have certain similarities with conventional investment funds, which are reflected primarily in the way of raising funds. Investment funds collect funds by issuing and selling investment units, while in
Islamic banks, the most important financing sources are investment deposits based on mudarabah system, whose owners have rights and obligations similar to rights and obligations of the investment units' owners. However, Islamic banks have additional sources of financing in the form of transaction deposits whose principal is guaranteed to their owners. These deposits can be withdrawn at any time, but do not bring income to their owners. Also, Islamic banks are funded by issuing ordinary shares, whose owners have more rights than the owners of shares of investment funds. Therefore, it can be concluded that Islamic banks have much more heterogeneous liabilities compared to conventional investment funds. The implications of the differences in the liabilities' homogeneity between Islamic banks and investment funds can be best illustrated by comparing the position of the Islamic banks' investment deposits owners and the open-end funds' investment units owners, which have the following rights: the right to participate in profits, the right to be informed about business activities and the right to withdraw their investment. Comparison of statuses of these two types of investors can be done from theoretical and practical aspects.

When it comes to investment funds, practice does not go far away from theory and here, the role of the investor is usually fulfilled only by the owners of the investment units. On the other side, when it comes to Islamic banks, there are two categories of investors who have the right to participate in profits: shareholders and owners of investment deposits. Their statuses are not equal because shareholders have the right to manage the bank, while depositors do not. Therefore, the information is more accessible to shareholders, which leads to the emergence of asymmetric information and creates a space for the emergence of moral hazard, that is, abuse by the shareholders at the expense of depositors (such as concealing information about risk exposure and realized profits). Starting from the above mentioned, we can conclude that, theoretically, the position of the owner of investment units is more favorable in comparison to the position of the investment depositors because the rights of all investors in investment funds are identical. Truth be 
depozita, kako zbog ugovornih uslova, tako i zbog situacije da islamske banke uglavnom ulažu u nelikvidne finansijske instrumente (bazirane na partnerstvu, trgovini ili zakupu).

Sa druge strane, ako statuse vlasnika investicionih jedinica i vlasnika investicionih depozita poredimo s praktičnog aspekta, uočićemo da je razlika između njih u praksi često veća nego u teoriji. Naime, kod pojedinih islamskih banaka, vlasnici investicionih depozita nisu spremni da podele teret gubitka sa bankom, već u slučaju kada im profitna očekivanja nisu ispunjena povlače svoje uloge. Zbog toga islamske banke često odvajaju deo profita da bi formirale posebne rezerve za obezbeđenje isplate prinosa vlasnicima investicionih depozita. Da bi se osigurala isplata prinosa vlasnicima investicionih depozita, formiraju se rezerve za izjednačavanje dobiti (Profit Equalization Reserve - sredstva prikupljena izdvajanjem iz ukupne dobiti pre nego što banka uzme svoj deo dobiti) i rezerve rizika ulaganja (Investment Risk Reserve - sredstva prikupljena izdvajanjem iz dobiti vlasnika investicionih depozita, nakon što banka uzme svoj deo dobiti) (Iqbal and Mirakhor, 2009, str. 224-226). To dovodi do promene statusa vlasnika investicionih depozita, koji postaje sličan statusu preferencijalnih akcionara koji ne mogu upravljati akcionarskim društvom, ali imaju pravo na fiksnu dividendu. Stoga, zaključujemo da je u praksi položaj vlasnika investicionih depozita često sigurniji od položaja vlasnika investicionih jedinica.

Ipak, navedena praksa, i pored kratkoročne koristi koju deponenti islamskih banaka ostvaruju u vidu sigurnog prinosa, dugoročno po deponente, kao i po banku i kompletno islamsko finansijsko tržištemožeimatinegativne posledice. Naime, obaveza formiranja rezervi umanjuje investicione potencijale islamske banke i uskraćuje mogućnost ulaska u brojne unosne investicione projekte, koji zahtevaju visoka ulaganja i nose značajan rizik. Usled toga, islamske banke se uglavnom odlučuju na kratkoročna ulaganja u poslove trgovine (murabeha), koji dominiraju u njihovim plasmanima (Iqbal, Ahmad and Khan, 1998; Iqbal, 2007). Samim tim, zarađivački potencijali islamskih banaka ostaju nedovoljno iskorišćeni, usled čega će se vremenom smanjivati njihova sposobnost da ispunjavaju profitna očekivanja deponenata. U toj situaciji gube svi - islamske banke, koje neće imati adekvatnu finansijsku osnovu da budu konkurentne konvencionalnim finansijskim institucijama, deponenti, koji slabljenjem islamskih banaka gube priliku za šerijatski usklađenu štednju (ukoliko imaju takve preferencije) i kompletno islamsko finansijsko tržište, čiji su ključni akteri upravo islamske banke. Pored toga, obezbeđenje stabilnog prinosa ima svoju cenu i za vlasnike investicionih depozita, jer su oni primorani da se $u$ periodu uspešnog poslovanja odreknu dela profita koji se koristi za formiranje rezervi, kako bi u periodu stagnacije poslovanja banke mogli ostvariti očekivani prinos. Takođe, prisutan je i problem nedovoljne informisanosti deponenata o postupku formiranja rezervi i nemogućnosti da utiču na upotrebu ovako prikupljenih sredstava, od kojih više koristi mogu imati vlasnici dugoročnih nego vlasnici kratkoročnih investicionih depozita. Sredstva izdvojena iz dobiti deponenata banke često zadržavaju i nakon povlačenja depozita, tako da vlasnici kratkoročnih depozita praktično "subvencionišu prinos dugoročnih ulagača" (Iqbal and Mirakhor, 2009, str. 226).

Stoga, jedino rešenje može biti u razvijanju snažnog partnerstva između islamskih banaka i njihovih deponenata, gde će islamske banke $\mathrm{u}$ svom poslovanju uzimati $u$ obzir interese deponenata, a deponenti, s druge strane, biti spremni da dele rizik poslovnog neuspeha sa bankom. U teoriji još uvek postoje dileme, da li je postojeći status deponenata islamskih banaka adekvatan i koje su mogućnosti za njegovo unapređenje. Rešenja koja nalazimo u literaturi su (Grais and Pellegrini, 2006, str. 26-27): 1. izjednačiti prava investicionih deponenata i akcionara, 2. izjednačiti prava investicionih deponenata i klasičnih poverilaca i 3. uključiti predstavnika investicionih deponenata $\mathrm{u}$ upravljačke strukture banke. Međutim, sva tri pristupa ostala su i dalje na nivou predloga ili sporadičnih slučajeva njihove realizacije. Za to postoje sledeći razlozi: 1 . investicioni deponenti ne mogu imati beneficije akcionara sve dok ne budu u poziciji da svoje uloge ponude tržištu, kao što akcionari mogu ponuditi svoje akcije, jer bez toga sloboda upravljanja ulaganjima je veoma ograničena, 2 . investicioni deponenti ne 
told, the owners of investment units can also encounter the problem of inadequate access to information, but their position is more secure due to possibility to, in any given moment, withdraw their investment. In order to fulfill the payment obligation, investment funds invest into highly liquid financial instruments which are easily marketable, so that in the short term they can secure money for payment to withdrawing investors. Withdrawal of investment is significantly more complicated in case of the Islamic banks' investment deposits, not only because of the agreement conditions but also due to the fact that Islamic banks invest mostly in non-liquid financial instruments (based on partnership, trade or lease).

On the other side, if we compare the status of owners of investment units and owners of investment deposits from the practical aspect, we will notice that the difference between them is in practice often larger than it is in theory. Namely, when it comes to some Islamic banks, owners of investment deposits are not ready to share the burden of loss with the bank, so in the case when their profit expectations are not fulfilled, they withdraw their investments. Thus, Islamic banks often separate part of the profit in order to form special reserves for securing the payment of income to the owners of investment deposits. In order to secure the payment of income to owners of investment deposits, Islamic banks form the Profit Equalization Reserve - i.e. the funds raised from profits before the bank takes its part of the profit, and the Investment Risk Reserve - i.e. the funds raised from the investment deposits owners' part of the profit, after the bank takes its part of the profit (Iqbal and Mirakhor, 2009, p. 224-226). This brings the change of status of the owner of investment deposits, which becomes similar to the status of the preferential shareholders who cannot manage the company, but they have the right to a fixed dividend. Therefore, we can conclude that in practice, the investments of the investment deposits' owners are often more secure than the investments of the investment units' owners.

Nevertheless, the above mentioned practice, apart from the short-term benefit which depositors of Islamic banks realize through certain profit, can have negative long-term effects for the depositors, as well as for the banks and the entire Islamic financial market. Namely, the obligation of forming reserves decreases investment potential of the Islamic banks and decreases the possibility of entering numerous lucrative projects, which require high investments and carry significant risks. Consequently, Islamic banks mainly decide to make short-term investments in trade business (murabahah), which is predominant in their investments (Iqbal, Ahmad and Khan, 1998; Iqbal, 2007). Therefore, the earning potential of Islamic banks remains insufficiently used, which in turn decreases their ability to fulfill profit expectations of the depositors. In this situation, everybody loses - the Islamic banks, which will not have adequate financial basis to compete with conventional financial institutions, the depositors, who will lose opportunity for Sharia adjusted savings (in case they have such preference) and the complete Islamic financial market, whose key actors Islamic banks are. Moreover, the security of stable income has its price for the owners of investment deposits as well, because they are forced to, during the period of successful business, give up part of the profit which is used for formation of reserves, in order to realize their expected profit in the period of stagnation of the bank's businesses. Also, there is a problem of insufficient information provided to depositors about the process of formation of reserves and their inability to influence the use of collected funds, from which the owners of long-term investment deposits have more benefit compared to the owners of short-term investment deposits. The funds separated from the depositors' part of profit are often kept by the banks even after the withdrawal of deposits, so that the owners of short-term deposits can practically "subsidize the income of the long-term investors" (Iqbal and Mirakhor, 2009, p. 226).

Therefore, the only solution lies in developing strong partnership between the Islamic banks and their depositors, where the Islamic banks will take into consideration the interests of their depositors, and on the other side, depositors will be ready to share the risks of a business failure with the bank. In theory, there is still a dilemma if the existing status of the Islamic banks' depositors is adequate and what the possibilities are for its enhancement. The solutions found in literature are as 
mogu imati status poverilaca, jer je to protivno principima islamskog bankarstva i 3. upitno je koliko bi prava investicionih deponenata bila zaštićenija uključivanjem njihovih predstavnika u upravljačke strukture, jer je realno očekivati da bi pre došlo do jačanja agencijskog problema (Grais and Pellegrini, 2006, str. 27) usled pojave novih principala (investicioni deponenti) $i$ agenata (predstavnici investicionih deponenata), nego do unapređenja statusa investicionih deponenata.

\section{Zaključak}

Islamske banke su finansijske institucije čije je poslovanje šerijatski usklađeno, što podrazumeva, između ostalog, i zabranu upotrebe kamate prilikom plasiranja i prikupljanja novčanih sredstava. U skladu s tim, finansiranje islamskih banaka najvećim delom se bazira na prikupljanju investicionih depozita, čiji vlasnici postaju partneri islamske banke (bez prava na upravljanje). Njihov status je sličan statusu ulagača kod investicionih fondova zbog toga što $u$ oba slučaja ulagači imaju pravo na udeo u ostvarenoj dobiti finansijske institucije kojoj su poverili svoj novac, ali nemaju pravo na upravljanje investicijom. Ipak, pomenuta sličnost je često izraženija $u$ teoriji nego u praksi. Teoretski posmatrano, ulagači u investicione jedinice investicionih fondova su u izvesnoj prednosti jer svi ulagači imaju ista prava i obaveze. Kod islamskih banaka, s druge strane, pravo na udeo u dobiti imaju investicioni deponenti i akcionari banke, koji imaju značajnu prednost jer imaju pravo na upravljanje bankom i lakši pristup informacijama o poslovanju banke. To investicione deponente stavlja u podređen položaj i izaziva pojavu asimetrične informisanosti i moralnog hazarda. Investicioni deponenti su svesni ovog problema, pa u praksi vrše pritisak na banke da im pruže dodatnu sigurnost kroz obezbeđenje sigurne isplate očekivanog prinosa. Da bi mogle da izađu u susret ovakvim zahtevima, islamske banke formiraju posebne rezerve, zahvatanjem dela profita banke i deponenata. Na taj način, položaj investicionih deponenata postaje sigurniji $\mathrm{u}$ odnosu na položaj onih koji ulažu u investicione fondove, ali ova praksa izaziva brojne kontroverze. Najpre, investicioni deponenti, faktički prestaju biti partneri banke i stiču status sličan onom koji imaju preferencijalni akcionari ili čak poverioci, što je protivno šerijatskim principima. Drugo, formiranje rezervi je često netransparentan proces koji može ići na štetu samih investicionih deponenata. Treće, formiranje rezervi i implicitna obaveza islamske banke da investicionim deponentima garantuje prinos, sprečava islamske banke da ulažu u razvojne projekte, koji nose značajan prinos, ali i visok rizik, čime se limitira zarađivački potencijal islamskih banaka i ugrožava njihova konkurentnost. Time gube i deponenti i islamsko finansijsko tržište. Status investicionih deponenata predmet je rasprave $\mathrm{u}$ islamskim ekonomskim krugovima. Postoje predlozi za unapređenje njihovog statusa, ali mnogi od njih još uvek nisu našli praktičnu primenu, zbog otežane praktične primene ili zbog narušavanja principa islamskog bankarskog poslovanja. $\mathrm{Na}$ kraju, treba naglasiti da pri ulaganju u islamske banke, investicioni deponenti treba da budu svesni da ne mogu očekivati nivo sigurnosti koji se pruža onima koji ulažu u konvencionalne investicione fondove $\mathrm{u}$ razvijenim zemljama. Investicioni fondovi pružaju sigurnost svojim ulagačima prevashodno zbog činjenice da značajan deo njihove aktive čine visokolikvidne i lako utržive kratkoročne hartije od vrednosti, koje se baziraju na kamati, pa samim tim su nedostupne islamskim bankama. Koristi koje investicioni deponenti mogu očekivati od ulaganja u islamske banke su viši nivo prinosa $i$ šerijatski usklađeno ulaganje novca koji banci poveravaju, što bi trebalo da bude veoma bitno onima koji se opredeljuju za štednju u islamskim bankama. 
follows (Grais and Pellegrini, 2006, p. 26-27): 1. equalize the rights of investment depositors and shareholders, 2. equalize the rights of investments depositors and classic trustees, and 3. include the representatives of investment depositors in the managing structures of the bank. However, all three approaches still remain at the level of proposal with only a few sporadic cases of their realization. There are several reasons behind this: 1 . investment depositors cannot have benefits of shareholders until they are in the position to offer their stakes to the market, just as shareholders can offer their shares, because otherwise the freedom of managing investments is very limited, 2 . investment depositors cannot have the status of trustees because it is against the principles of the Islamic banking, and 3. it is questionable how much the rights of investment depositors would be protected with the involvement of their representatives in the managing structure, since it is expected that it would amplify agency problems (Grais and Pellegrini, 2006, p. 27) due to the emergence of new principles (investment depositors) and agents (representatives of investment depositors), rather than enhance the status of the investment depositors.

\section{Conclusion}

Islamic banks are financial institutions whose business is Sharia compliant, which implies, among other things, prohibition of the use of interest in investing and raising funds. In regard to this, the financing of Islamic banks is mostly based on raising investment deposits, whose owners become partners of the Islamic bank (without the right to manage the bank). Their status is similar to the status of investors in investment funds because in both cases investors have the right to participate in the realized profit of financial institutions entrusted with their money, but they do not have the right to manage the institution. However, the mentioned similarity is often more expressed in theory than in practice. Theoretically, investors who invest in the investment funds' investment units have slight advantage because all the investment funds' investors have the same rights and obligations. When it comes to Islamic banks, on the other side, investment depositors and shareholders have the right to participate in the realized profit, which gives shareholders significant advantage because they also have the right to manage the bank and

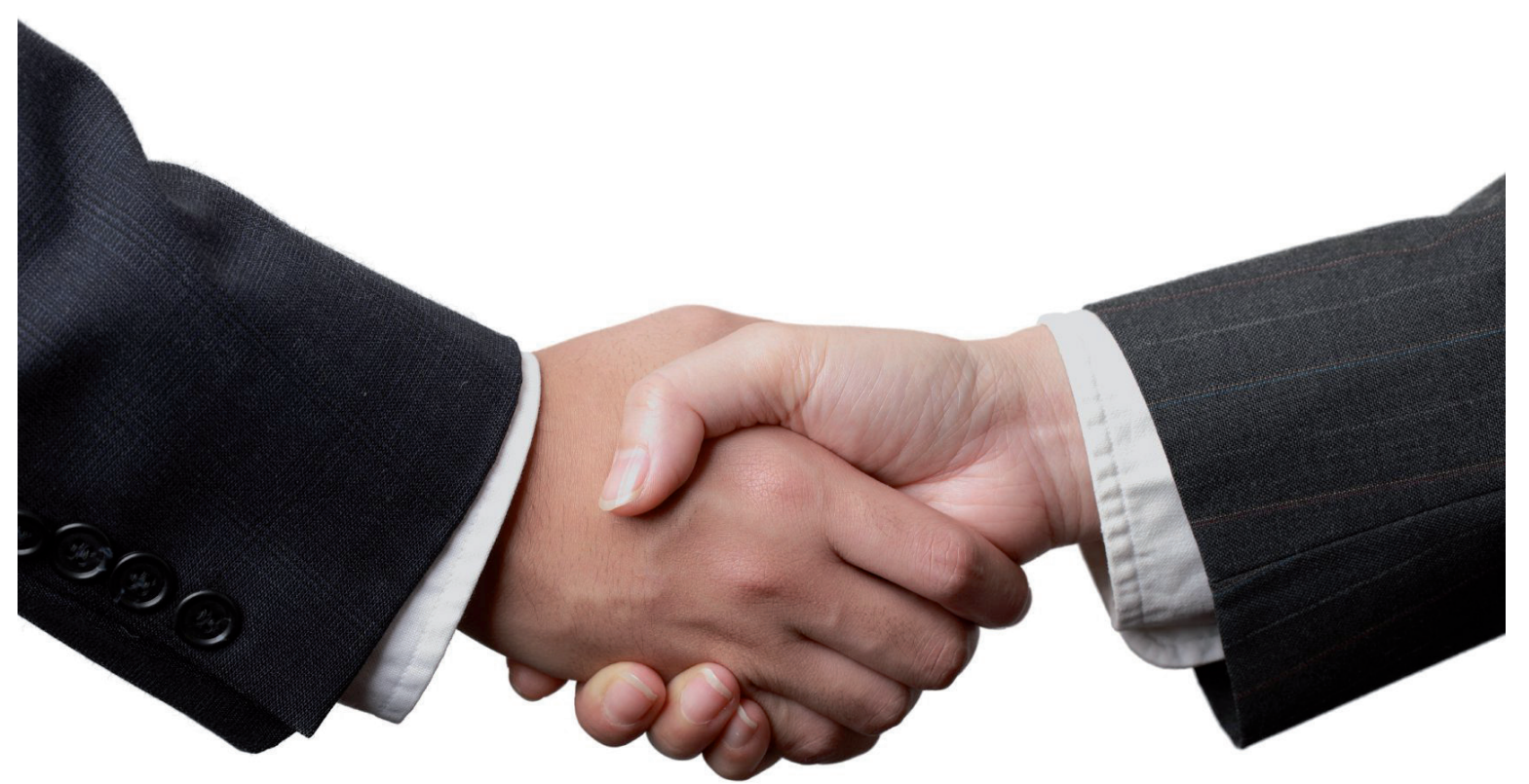




\section{Literatura / References}

1. Al-Dhareer, S. 1997. Al-Gharar in contracts and its effects on contemporary transactions. Jeddah: Islamic Research and Training Institute, Islamic Development Bank

2. Ayub, M. 2007. Understanding Islamic Finance. John Wiley and Sons Ltd.

3. Chapra, U. 2000. Why has Islam prohibited interest? Rationale behind the prohibition of interest. Review of Islamic Economics, (9): 5-20

4. Chapra, U. 2006. The Nature of Riba in Islam. The Journal of Islamic Economics and Finance 2, (1): 7-25

5. Dusuki, A. W., \& Dar, H. 2007. Stakeholders' Perceptions of Corporate Social Responsibility of Islamic Banks: Evidence from Malaysian Economy. U: Iqbal, M., Ali, S., \& Muljawan, D. (Ed.), Advances in Islamic economics and finance (249-277). Jeddah: Islamic Research and Training Institute, Islamic Development Bank

6. Elfakhani, S., Sidani, Y., \& Fahel, O. 2004. An Assessment of the Performance of Islamic Mutual Funds. The European Journal of Management and Public Policy 3, (1): 41-64

7. Erić, D. 2003. Finansijska tržišta i instrumenti. Beograd: Čigoja štampa

8. Farook, S. 2007. On corporate social responsibility of Islamic financial institutions. Islamic Economic Studies 15, (1): $31-46$

9. Grais, W., \& Pellegrini, M. 2006. Corporate Governance of Business Offering Islamic Financial Services: Issues and Options (Working Paper No. 4052). http://papers. ssrn.com/sol3/papers.cfm?abstract_ $\mathrm{id}=940709.28 .10 .2015$.

10. Hadžić, F. 2005. Islamsko bankarstvo $i$ ekonomski razvoj. Sarajevo: Ekonomski fakultet

11. Investment Company Institute. 2015. 2015 Investment Company Fact Book: A Review of Trends and Activity in the U.S. Investment Company Industry. https://www.ici.org/ pdf/2015_factbook.pdf

12. Iqbal, M., Ahmad, A., \& Khan, T. 1998. Challenges Facing Islamic Banking. Jeddah: Islamic Research and Training Institute, Islamic Development Bank
13. Iqbal, Z. 2007. Challenges facing Islamic financial industry. Journal of Islamic Economics, Banking and Finance 3, (1): 1-14

14. Iqbal, Z., \& Mirakhor, A. 2009. Uvod u islamske financije: teorija i praksa. Zagreb: Mate

15. Khan, M., \& Bhatti, M. I. 2008. Developments in Islamic Banking: The Case of Pakistan. Palgrave Macmillan

16. Lekpek, A. 2013. Islamski bankarski ugovori. Anali Pravnog fakulteta u Beogradu 61, (1): 299-313

17. Mahoney, P. 2004. Manager-Investor Conflicts in Mutual Funds. Journal of Economic Perspectives 18, (2): 161-182

18. Marinković, S. 2008. Finansijsko tržište $i$ finansijske institucije u Republici Srbiji. Niš: Ekonomski fakultet

19. Pozen, R., \& Hamacher, T. 2011. The Fund Industry: How Your Money is Managed. Hoboken, New Jersey: John Wiley and Sons, Inc.

20. Rahman, F. 2005. Islam. Sarajevo: Tugra

21. Rouwenhorst, K. G. 2004. The Origins of Mutual Funds (Yale ICF Working Paper No. 04-48). http://papers.ssrn.com/sol3/papers. cfm?abstract_id=636146. 20.10.2015.

22. Siddiqi, M. 2004. Riba, bank interest and rationale of its prohibition. Jeddah: Islamic Research and Training Institute, Islamic Development Bank

23. U.S. Securities and Exchange Commission. (1940) 1988. Investment Company Act of 1940. https://www.sec.gov/about/laws/ ica40.pdf. 20.10.2015.

24. U.S. Securities and Exchange Commission. Mutual Funds. http://www.sec.gov/ answers/mutfund.htm. 20.10.2015.

25. Usmani, M. 2003. Uvod u islamske finansije. Živinice: Selsebil

26. Van Greuning, H., \& Iqbal, Z. 2008. Risk Analysis for Islamic Banks. Washington D.C.: The International Bank for Reconstruction and Development, The World Bank

27. Yusuf, M. Y., \& Bahari, Z. B. 2011. Islamic Corporate Social Responsibility in Islamic Banking; Towards Poverty Alleviation. U: 8th International Conference on Islamic Economics and Finance "Sustainable Growth and Inclusive Economic Development from an Islamic Perspective“.19-21.12.2011. Doha, Qatar: Qatar Faculty Of Islamic Studies 
enjoy easier access to the information of bank's businesses. This puts investment depositors in a subordinate position and causes the emergence of asymmetric information and moral hazard. Investment depositors are aware of this problem which is why they put pressure on the banks to offer them additional security through ensuring the secure payment of expected profit. In order to meet these demands, Islamic banks form special reserves including part of the profit of the bank and the depositors. In this way, the position of investment depositors becomes more secure in comparison to the position of those who invest in investment funds, but this practice causes various controversies. First of all, investment depositors, in fact, cease to be partners of the bank and they gain the status similar to that of preferential shareholders or even trustees, which is against the Sharia principles. Secondly, the formation of reserves is often not transparent which can cause damage to the investment depositors. Thirdly, the formation of reserves and implicit obligation of the Islamic bank to guarantee profit to the investment depositors prevents Islamic banks from investing in development projects, which can incur significant profit but also very high risks. That can limit the earning potential of Islamic banks and threaten their competitiveness. In this way, not only depositors lose but also the Islamic financial market. The investment depositors' status is under debate in Islamic economic circles. There are proposals for the improvement of their status, but many of them have still not been implemented in practice due to the various difficulties or the violation of the Islamic banking principles. Finally, when investment depositors invest in Islamic banks, they should be aware that they cannot expect the level of security that is provided to those who invest in conventional investment funds in the developed countries. Investment funds provide security for their investors, primarily due to the fact that a significant part of their assets are highly liquid and easily marketable shortterm securities, which are based on interest, and therefore unavailable to Islamic banks. Benefits which investment depositors can expect from investing in Islamic banks are higher yields and Sharia adjusted investment of money which they deposit in the bank, which should also be very important to those who decide to entrust their savings to the Islamic banks. 